\section{Kư KAstamonu Eğitim Dergisi Kastamonu Education Journal}

Ocak 2019 Cilt:27 Sayı:1

kefdergi.kastamonu.edu.tr
Başvuru Tarihi/Received: 04.10.2017

Kabul Tarihi/Accepted: 13.02.2018

DOI: $10.24106 /$ kefdergi.2306

\title{
Ergenlerin Saldırganlık Düzeyinin Değer Yönelimleri, Cinsiyet ve Anne Babanın Eğitim Düzeyi Açısından Yordanması
}

\section{The Prediction of Adolescents' Aggression Levels in Terms of Value Orientations, Gender and Parents' Education Level}

\section{Öz}

\author{
Zöhre KAYA ${ }^{1}$, Fatma Ebru íkiZ², Esra ASICl $^{3}$
}

Bu çalışmanın amacı, ergenlerin değer yönelimlerinin, cinsiyet ve anne-baba eğitim durumunun saldırganlığı yordayıp yordamadığını incelemektir. Araştırma yordayıcı korelasyonel araştırma modeline dayalı olarak tasarlanmıştr. Araştırmanın katılımcılarını 890 ergen oluşturmuştur. Araştırmanın verileri, Saldırganlık Ölçeği, Portre Değerler Anketi ve Kişisel Bilgi Formu aracılığıyla toplanmıştır. Analizlerde, aritmetik ortalama, Pearson korelasyonu ve hiyerarşik regresyon analizi teknikleri kullanılmıştır. Sonuçlar, saldırganlık düzeyi ve değer yönelimleri arasında negatif ilişki olduğunu, değer yönelimleri, cinsiyet ve anne babanın eğitim düzeyi değişkenlerinin birlikte saldırganIık puanlarındaki değişimin \%18.7'sini açıkladığı tespit edilmiştir. Elde edilen sonuçlara göre başarı, evrenselcilik ve iyilikseverlik değerlerinin saldırganlığın azalmasına, baba eğitim düzeyinin ise saldırganlığın artmasına istatistiksel olarak anlamlı düzeyde katkı sağladığını; özyönetim, uyma ve güvenlik değerleri ile cinsiyet ve annenin eğitim düzeyi değişkenlerinin saldırganlığı yordamadaki etkisinin istatistiksel olarak anlamlı düzeyde olmadığı belirlenmiştir.

Anahtar Kelimeler: Fiziksel saldırganlık, Sözel saldırganlık, öfke, düşmanlık, değer yönelimleri, cinsiyet, anne-baba eğitim durumu, ergen

\section{Abstract}

The purpose of this study is to examine whether value orientations of adolescents, gender and state of parents' education predict aggression. The study was designed as predictive correlational research model. The participants consisted of 890 adolescents. Data were collected by Aggression Scale, Portrait Values Scale and a personal information questionnaire. Data were analyzed through mean, Pearson correlation and hierarchical regression analysis. Results indicated that there was significant negative correlation between aggression levels and value orientations of adolescent. It was found that value orientations, gender and parents' education level together explained $18.7 \%$ of the variance of aggression in adolescence. Findings showed that success, universalism, benevolence and education level of father significantly contributed to prediction of aggression in adolescents while the contributions of the security, conformity, self-direction, gender and education level of mother were not significant.

Keywords: Physical aggression, verbal aggression, anger, hostility, value orientations, gender, state of parent's education, adolescence

\footnotetext{
1. Van Yüzüncü Yıl Üniversitesi, Eğitim Fakültesi, Eğitim Bilimleri Bölümü, Van, Türkiye; https://orcid.org/0000-0001-9211-3632

2. Dokuz Eylül Üniversitesi, Buca Eğitim Fakültesi, Eğitim Bilimleri Bölümü, İzmir, Türkiye; https://orcid.org/0000-0003-4381-1658

3. Kilis 7 Aralık Üniversitesi, Muallim Rıfat Eğitim Fakültesi, Eğitim Bilimleri Bölümü, Kilis, Türkiye; https://orcid.org/0000-0003-0872-9042

Atıf / Citation: Kaya, Z., İkiz, F.E., \& Asıcı, E. (2019). Ergenlerin saldırganlık düzeyinin değer yönelimleri, cinsiyet ve anne babanın eğitim düzeyi açısından yordanması. Kastamonu Education Journal, 27(1), 75-84. doi:10.24106/kefdergi.2306
} 


\section{Extended Abstract}

Introduction and Purpose: Aggressive behaviors and tendencies are important problem areas in adolescence. Aggression is a structure consisted of physical and verbal aggression, anger and hostility dimensions and it is indicated to have affective, behavioral and cognitive components. Since aggressive behaviors are still prevalent between adolescents (Aygen \& Acik, 2014; Kepenkci \& Cinkir, 2005; Unlu, Evcin, Burakgazi Yılmaz, \& Dalkilic, 2013) it means that there is still something more to be investigated. Since aggressive expressions result in many negative emotional, physical and behavioral consequences (Campano \& Munakata, 2004), the triggering factors are thought to be important to investigate. We know that aggressive expressions are learned through socialization processes (Akkas \& Uyanik, 2016) that may increase during the social interactions between adolescents (Steinberg, 2013) because of the effects of their biological and hormonal changes. So it is offered that the value systems of adolescents may underlie these expressions (Benish- Weisman \& McDonald, 2015). Values, as a motivational structure, are explained by behavioral patterns, attitudes and preferences that function as standards to reach a purpose for a person (Schwartz \& Sagie, 2000). These values may occur by the effects of social environmental dynamics either during the interactions at home with family members, or within the peer interactions. Values are indicated to be the vital manipulative agencies for adolescents to behave accordingly (Kisac \& Turan, 2015). According to literature, the relation between values and aggression of adolescents is not clear and there were found studies which were indirectly investigating the phenomena. For example, Sussman, Skara, Weiner and Dent (2004) emphasized that the attitudes of adolescents towards problem behaviors were effective on violence tendencies. This means that it is valuable to investigate the direct relationship between aggression and value orientations of adolescents, the predictive effects of values towards the aggression levels of adolescents. Moreover, it is thought to be important that whether gender and parental education level may have discriminative effects on predicting the aggression levels of adolescents or not. The purpose of this study is to determine the relationship between aggression levels and value orientations of adolescents, the predictive role of values orientations, gender and parental education levels on aggression in adolescents.

Method: Present study is based on relational surveying model. Participants were composed of 890 adolescents, who were attending to vocational high schools in western region of Turkey, in Izmir during 2014-2015 education term. According to gender, participants indicated that \%76.2 (n:678)of them were female, \%23.8 (n:212) of them were male. Data were collected by Portrait Values Questionnaire which was originally developed by Schwartz et all (2001) and adapted to Turkish by Demirutku and Sumer (2010, with Aggression Questionnaire which was originally developed by Buss and Perry (1992) and adapted to Turkish by Sumer (2003) were used with a demographic questionnaire which was developed by the researchers. Validity and reliability studies of these two scales were made for adolescents in present study. Data were analyzed by descriptive statistics, pearson correlation and hierarchical regression analysis.

Findings: According to the investigation of the aggression levels and value orientations of adolescents, it was found that the highest means were gathered on physical aggression, the lowest means were gathered on anger levels. According to value orientations, it was found that the highest means were gathered on universalism, the lowest means were gathered on security and benevolence levels. According to the investigation of the relation between the aggression levels and value orientations of adolescent, results indicate significant negative correlations between aggression levels and values orientations of adolescents.

According to the results of hierarchical regression analysis, while success $(\beta=-0,14 ; t=-3,35 ; p<0,01)$, universa$\operatorname{lism}(\beta=-0,27 ; t=-5,94 ; p<0,05)$ and benevolence $(\beta=-0,09 ; t=-2,21 ; p<0,05)$ value orientations made negative and significant contributions to regression model; the education levels of father $(\beta=0,08 ; t=2,40 ; p<0,05)$ made positive and significant contributions. Success, universalism, benevolence and the education level of father all together explain $18.7 \%$ of the variance of aggression in adolescence.

Conclusion and Discussion: The purpose of this study is to determine the relationship between aggression levels and value orientations of adolescents and the predictive role of values orientations, gender and parental education levels on aggression in adolescents. As a conclusion, there are significant negative correlations between aggression levels and values orientations of adolescents. We can say that, especially for vocational high school populations, the increase in value orientations of adolescents lead to decrease in their aggression levels. Especially some values were found to be more important than the others for these participants. These were success values, benevolence values and universalism values. Remembering that values are important manipulative agencies and motivational resources for adolescents to behave accordingly (Kisac \& Turan, 2015); vocational high school students need to be enhanced to internalize success, universalism and benevolence values to experience them rather than aggression. By the way, these results of this study are consistent with the literature emphasizing that there is negative correlation between moral attitudes and aggression (Avci, 2010); character education (Cokdolu, 2013) and peace education (Sagkal, 2011) have positive effects on decreasing aggression levels of adolescents. According to the results of present this study, the need to support and educate adolescents on values and also on how to manage their anger and hostility arises. Supportive and preventive school counseling is offered to be more effective to protect and enhance the mental health of adolescents and to support living together in harmony. 


\section{Giriş}

Saldırganlık ergenler arasında karşılaşılan en yaygın problem alanlarından birisidir. Geçmişten bu yana saldırganlığı önlemek amacıyla ergenlerin saldırgan davranış ve eğilimlerinin nedenlerini anlamaya yönelik araştırmalar gerçekleştirilmesine rağmen; ergenler arasında saldırgan davranışların hala yaygın olduğu (Aygen ve Açık, 2014; Kepenkçi ve Çınkır, 2005; Ünlü, Evcin, Burakgazi Yılmaz ve Dalkılıç, 2013) görülmektedir. Bu durum sosyal, duygusal, fiziksel ve davranışsal pek çok olumsuz sonuç yaratan (Campano ve Munakata, 2004) ergenlerin saldırgan davranışlarına yönelik olarak daha etkili önleyici ve çözüm bulucu yaklaşımlar geliştirebilme yönünde halen bir ihtiyaç olduğunu ve bu nedenle de saldırganlığı tetikleyen faktörlerin incelenmesinin önemini ve güncelliğini koruyan bir konu olduğunu ortaya koymaktadır.

En genel haliyle başkalarını incitme veya başkalarına zarar verme amacıyla yapılan her türlü davranış veya eylem (Freedman, Sears ve Carlsmith, 1998) olarak tanımlanabilen saldırganlık konusu çok sayıda kuramcı tarafindan araştrılmakla birlikte, saldırganlığın nasıl tanımlanacağı konusunda bir görüş birliği bulunmamaktadır. Bandura (1973) saldırganlığı sosyal kuralları bozan ya da yıkan zarar verici davranış kalıpları içinde değerlendirirken; Berkowitz (1987) saldırganlığı "niyet" kavramıyla birlikte açıklamakta ve canlı veya cansız herhangi bir varlığa karşı fiziksel ya da duygusal olarak zarar vermeyi amaçlayan davranış olarak tanımlamaktadır. Buss ve Perry (1992) ise saldırganlığın sözel ve fiziksel saldırganlık ile öfke ve düşmanlık boyutlarından oluşan çok boyutlu bir yapı olduğunu ve birbiriyle ilişkili olan bu boyutların saldırganlığın duyuşsal, davranışsal ve bilişsel bileşenlerini oluşturduğunu belirtmektedir. Görüldüğü gibi, saldırganlık kavramına ilişkin tanımlarda yıllar içerisinde değişim meydana geldiğini, saldırganlığın 70'li yıllarda zarar verici davranış şeklinde basit bir tanımla açıklanırken; 90'ı yıllara gelindiğinde çok boyutlu ve daha karmaşık bir yapı olarak ele alınmaya başlandığını söylemek mümkündür.

Saldırganlığın bilişsel, duyuşsal ve davranışsal bileşenleri tanımsal olarak birbirinden farklılaşmaktadır. Saldırganlığın bilişsel bileşeni olan düşmanlık, bireyin diğerlerinden hoşlanmama duygusunu ifade etmekte, diğerlerini olumsuz olarak değerlendirmeye neden olmakta ve saldırgan davranışın başlatıcısı olarak görülmektedir (Nugent ve Champling, 1997). Saldırganlığın duyuşsal bileşeni olan öfke, doğal-biyolojik olarak limbik sistemden kaynaklanmakta ve insanların günlük yaşamında deneyimlediği bir duygu olarak tanımlanmaktadır. Saldırganlığın davranışsal bileşenlerinden olan sözel saldırganlık, dışa vurulmuş öfke olarak; fiziksel saldırganlık ise motor davranışlarla ilişkili karşısındaki kişi ve objeye zarar verme amaçlı davranış olarak açıklanmaktadır (Buss ve Perry,1992). Yapılan çalışmaların büyük bölümünde olduğu gibi bu çalışmada da saldırganlık; düşmanlık, öfke, sözel saldırganlık ve fiziksel saldırganlık şeklindeki yukarıda açıklanan dört boyutlu yapıyla ele alınmaktadır.

Toplumsallaşma sürecinde öğrenildiği (Akkaş ve Uyanık, 2016) ve meydana gelen biyolojik değişimlerle birlikte ergenlik döneminde sosyal ilişkilerde artş gösterebildiği vurgulanan (Steinberg, 2013) saldırgan davranışların anlaşılmasında ergenin sahip olduğu değerler sisteminin önemli olduğu ileri sürülmektedir (Benish- Weisman ve McDonald, 2015). Bireyin yaşamına yön veren ve önem dereceleri farklı olan, arzulanan amaçlar olarak tanımlanabilen (Schwartz ve Sagie, 2000) değerler; bireyin yaşantıları ve içinde bulunduğu sosyal çevrenin etkisiyle oluşmakta ve insan davranışlarını yönlendiren etkenlerden biri olarak görülmektedir (Kısaç ve Turan, 2015).

Aile, okul ve arkadaş ortamındaki sosyalleşme sürecinde kazanılan değerler sistemi ergenin davranışlarının oluşmasında etkili olmakta; yapmış olduğu davranışların kabul edilebilir ya da kabul edilemez olduğunu belirleyerek o davranışı yapıp yapmama konusunda ergene ipuçları sunmaktadır (Göldağ, 2015). Değerler, sadece fikirlerle ilişkili değildir; bireyin duyguları, amaçları ve o bireyi bu amaçlara götüren davranış örüntüleriyle de ilişkili olup davranış, tutum ve tercihlerin standartları olarak işlev görmektedir (Kuşdil ve Kağıtçıbaşı, 2000). Bu doğrultuda Erikson'un psikososyal gelişim kuramına göre uygun bir kimlik ve hayat felsefesi bulma arayışı içinde olunan ergenlik sürecinde kritik bir öneme sahip olan değerlerin (Kısaç ve Turan, 2015) ergenlerin saldırgan davranışlarının anlaşılmasına yardımcı olacağı düşünülmektedir.

Bireyin davranışsal tercihlerine rehberlik eden (Koruklu ve Aktamış, 2012) değerler (1) biyolojik ihtiyaçlar, (2) sosyal etkileşimleri düzenlemeyle ilgili intiyaçlar ve (3) grup ve toplumsal gereklilikleri yerine getirmeyle ilgili ihtiyaçlar olmak üzere üç evrensel ihtiyacın bilişsel temsilcilerinden oluşmaktadır (Demirutku ve Sümer, 2010). Bu üç evrensel ihtiyaç bir araya gelerek iki temel güdüsel çatş̧ma ekseni üzerinde yer alan, dört boyut altında toplanan, birbiriyle uyumlu ve birbiriyle çatş̧an 10 değer yönelimini ortaya çıkarmaktadır. Birinci eksen yeniliğe açıklık ve muhafazakârlık, ikinci eksen de özgenişletim ve özaşkınlık boyutlarından oluşmaktadır. Yeniliğe açıklık boyutu bireysel yenilik arayışı, bağımSIz düşünme ve davranma yönelimini anlatan "uyarılma" ve "özyönelim" değer yönelimlerini; muhafazakârlık boyutu ise bireysel isteklerin toplumsal normlara ve geleneklere göre sınırlandırılmasını, bireysel ve toplumsal istikrarın korunmasını anlatan "uyma", "geleneksellik" ve "güvenlik" değer yönelimlerini içermektedir. Üçüncü boyut özgenişletim bireysel başarı ve baskınlığa vurgu yapan "güç" ve "başarı"; dördüncü boyut özaşkınlık ise diğerleri ve doğanın iyiliğini 
istemeye vurgu yapan "evrenselcilik" ve "iyilikseverlik" değer yönelimlerini içermektedir. Hem yeniliğe açıklık hem de özgenişletim boyutlarında yer alabilen "hazcılık" da onuncu değer yönelimi olarak tanımlanmaktadır (Demirutku ve Sümer, 2010; Schwartz, 1992; 1996).

İlgili alanyazın incelendiğinde; saldırgan davranışlar ve değer yönelimleri arasındaki ilişkileri ergenler açısından ele alan sınırlı sayıda araştırmanın var olduğu görülmektedir. Paciello ve arkadaşları (2017) özgenişletim boyutundaki güç ve başarı değer yönelimlerinin ergenlerde antisosyal davranışlara neden olan motivasyonel faktörler olabileceğini ileri sürerken; Benish- Weisman ve McDonald (2015) araştırmalarında saldırgan davranışların özgenişletim ve yeniliğe açıklık ile olumlu yönde; özaşkınlık ve muhafazakârlık ile de olumsuz yönde ilişkili olduğunu ortaya koymaktadır. Geç ergenler olarak tanımlayabileceğimiz meslek yüksekokulu öğrencilerinin katılımıyla ülkemizde gerçekleştirilen bir araştrrmada ise şiddet eğilimi yüksek olan bireylerin güç, başarı ve uyarılma değerlerine şiddet eğilimi düşük olan bireylere göre daha fazla önem verdikleri görülmektedir (Göldağ, 2015).

Saldırganlık ve değer yönelimlerinin birbirinden bağımsız olarak ele alındığı çalışmalar incelendiğinde; cinsiyetin saldırganlık (Aktaş ve Güvenç, 2006; Avcı ve Kelleci, 2015; Çeşit, 2016; Çetinkaya-Yıldız ve Hatipoğlu-Sümer, 2010; Haskan Avcı ve Yıldırım, 2015) ve bireyin sahip olduğu değer yönelimlerinde (Demirutku ve Sümer, 2010; Erden ve Yılmaz 2016; Göldağ, 2015; Güneş, 2015; Kısaç ve Turan, 2015; Schwartz ve Rubel, 2005; Sesli ve Demir Başaran, 2016) farklılıklar ortaya çıkaran önemli bir değişken olduğu göze çarpmaktadır. Ayrıca saldırganlığın akademik başarı (Güneş, 2015; Haskan Avcı ve Yıldırım, 2015); okul türü (Güneş, 2015); öfke (Avcı ve Kelleci, 2015); ebeveynlerin eğitim düzeyi (Yönet, Çalık, Yaşartürk ve Çimen; 20016); aile içi şiddet (Haskan Avcı ve Yıldırım, 2015); iletişim becerileri (Yıldırım ve Abakay, 2015); kişilerarası problem çözme becerileri (Arslan, Hamarta, Arslan ve Saygın, 2010) ve sportif faaliyetler (Yönet, Çalık, Yaşartürk ve Çimen; 2016) gibi çok çeşitli değişkenlerle ilişkili olduğu bilinmektedir. Değer yönelimleri ise akran ilişkileri (Erden ve Yılmaz, 2016); özerklik (Sesli ve Demir Başaran, 2016), akademik erteleme davranışı (Yiğit ve Dilmaç, 2011), akademik başarı (Güneş, 2015); sınıf düzeyi (Kısaç ve Turan, 2015; Sesli ve Demir Başaran, 2016; Yiğit ve Dilmaç, 2011), okul türü (Güneş, 2015; Kısaç ve Turan, 2015; Sesli ve Demir Başaran, 2016; Yiğit ve Dilmaç, 2011), ebeveynlerin eğitim düzeyi (Erden ve Yılmaz, 2016; Güneş, 2015; Sesli ve Demir Başaran, 2016; Yiğit ve Dilmaç, 2011) ve aylık gelir (Sesli ve Demir Başaran, 2016) gibi değişkenlerle ilişkili görünmektedir.

Değerlerle ilgili yapılan çalışmalar cinsiyet açısından incelendiğinde, erkeklerin başarı ve güç değerine verdiği önemin kadınlardan daha yüksek olduğu, kadınların evrensellik değerine ise erkeklerden daha fazla önem verdikleri (Demirutku ve Sümer, 2010) ileri sürülmektedir. Schwartz ve Rubel (2005), yaptıkları geniş çaplı araştırmada güç, uyarılım, hazcılık, başarı ve özyönelim değerlerinde erkeklerin; iyilikseverlik ve evrenselcilik değerlerinde kadınların daha yüksek puanlara sahip olduklarını gözlemlemiştir. Hatta bazı çalışmalarda (İmamoğlu ve Karakitapoğlu-Aygün, 1999., Karakitapoğlu-Aygün ve İmamoğlu, 2002), kadın ve erkeklerin değer yönelimlerinin benzerliğine dikkat çekilmiştir. Öne sürüldüğü üzere (Karababa ve Dilmaç, 2015), cinsiyetler arasındaki insani değer düzeylerinin ve değer tercihlerinin farklılığı, ailenin ve toplumun erkek ve kadın cinsiyetine yükledikleri rollerin ve anlayışların faklı olmasından kaynaklanabilir.

Son yıllarda eğitimin öncelikli konuları arasında yer alan değerlerin, disiplinler arası bir konu olarak çok çalışıldığı ve önemle üzerinde durulmaya devam edildiği görülmektedir. Değerler bireyin hayatını yönlendirmesinde toplumsal ve bireysel olarak önemli bir işleve sahiptir. Yukarıda yer verilen alan yazındaki bilgiler, ergenin problem davranışa ilişkin sahip olduğu tutumlarının şiddet davranışına yönelik eğilimini etkilediği (Sussman, Skara, Weiner ve Dent, 2004) görüşü doğrultusunda değerlendirildiğinde, saldırganlık ve değer yönelimleri arasındaki ilişkinin ve değer yönelimlerinin ergenlerin saldırganlık düzeyini yordamaya ne düzeyde katkı sağladığının araştırılması çalışılmaya değer bulunmaktadır. Yapılan bir çalışmada (Kepenkçi ve Çınkır, 2005), lise öğrencilerinin \%35.5'inin içinde bulunulan akademik yıl süresince en az bir kez fiziksel olarak şiddet davranışı sergiledikleri bulunmuştur. Ayrıca araştırmalar diğer lise türleriyle kıyaslandığında meslek lisesi öğrencileri arasında saldırgan davranışların daha yaygın olarak görüldüğünü ortaya koymaktadır (Başaran, 2008; Filiz, 2009). Günümüzde saldırgan davranışlardaki artışın özellikle de meslek lisesi öğrencileri arasında daha fazla olduğu dikkate alındığında, meslek lisesi öğrencilerine yönelik olarak önleyici ve çözüm bulucu yaklaşımların geliştirilmesinin önemli olduğu düşünülmektedir. Bu düşünceden yola çıkarak, meslek lisesi öğrencilerinin saldırgan davranışlarının açıklanmasında değerlerin rolünün incelenmesinin önemli olduğuna inanılmaktadır. Ayrıca, sosyalleşme olgusuyla bağlantılı olarak açıklanan saldırganlık ve değerlerin gerek cinsiyet açısından gerekse de sosyal öğrenmelerle ilişkili olarak ebeveynden etkilenmelerinin önemli oranda olduğu düşünülmektedir. Bu açıdan bakıldığında, ergenlerin saldırgan davranışları ve değer yönelimlerinde farklılıklar ortaya çıkarması beklenen cinsiyet ve anne-baba eğitim düzeyi değişkenlerinin ergenlerin saldırganlık düzeyini yordamadaki etkisinin belirlenmesinin alan yazına önemli katkılar sağlayacağına inanılmaktadır. Ortaya çıkan sonuçların ergenlere ve anne-babalara yönelik eğitsel ve psikolojik çalışmalar yürüten alanla ilgili çalışan uygulamacılara ve araştırmacılara veri sağlama açısından rehberlik edeceği; ön-

| Kastamonu Eğitim Dergisi, 27(1), 2019| 
leyici ve koruyucu çalışmalar açısından önemli bulgular ortaya çıkaracağı öngörülmektedir. Bu bilgiler doğrultusunda, bu araştırma kapsamında meslek lisesi öğrencilerinin değer yönelimlerinin, cinsiyet ve anne-baba eğitim düzeyinin saldırganlığı yordayıp yordamadığının incelenmesi amaçlanmıştır.

\section{Yöntem}

Araştırmanın Deseni: Bu araştırma, iki değişken arasındaki birlikte değişimin varlığını incelemeyi amaçlayan yordayıcı ilişkisel tarama modeline dayanmaktadır.

Araştırmanın kalıtımcıları: Araştırmanın katılımcılarını 2014-2015 eğitim öğretim yılında İzmir iline bağlı üç farklı meslek lisesinde okumakta olan ulaşılabilir örnekleme yöntemine göre belirlenen, araştırmaya katılmaya gönüllü olan \%76.2'si (n:678) kız, \%23.8'i (n:212) erkek olmak üzere toplam 890 öğrenci oluşturmaktadır. Öğrencilerin \%6,4'ünün annesi okuryazar değil, \%4'ünün okuryazar, \%47,5'inin ilkokul mezunu, \%22,9'nun lise, \%2,9'unun annesi üniversite mezunudur. Öğrencilerin \%2'sinin babası okuryazar değil, \%1,9'unun okuryazar, \%36,2'sinin ilkokul mezunu, \%25,6'sının lise, \%6,9'unun babası üniversite mezunudur.

\section{Veri Toplama Araçları ve Uygulama}

Saldırganlık Ölçeği (SÖ): Buss ve Perry (1992) tarafindan geliştirilen SÖ beşli Likert tipinde 29 maddelik bir ölçme aracıdır. Ölçeğin fiziksel, sözel saldırganlık, öfke ve düşmanlık olmak üzere dört alt boyutu bulunmaktadır. Ölçeğin Türkçe uyarlaması üniversite öğrencileri örnekleminde Sümer (2003) tarafindan yapılmıştı. Uyarlama çalışmasında ölçeğin toplam varyansın \%38'sini açıkladığı görülmüştür. SÖ’nün ergen örneklemi için geçerlik ve güvenirliği bu çalışma kapsamında test edilmiştir. Bu doğrultuda 29 maddelik ölçek formu için eldeki veri setiyle yapılan ilk DFA sonucunda elde edilen model uyum indekslerinin ölçeğin mevcut yapısını doğrulamak için yeterli olmadığı; faktör yükü .40'ın altında olan ve hata varyansı .90 'dan yüksek olan maddelerin var olduğu görülmüştür. Söz konusu maddeler ölçekten çıkarılarak (M4, M9, M11, M12, M14, M16, M19, M22, M26, M29) elde kalan 19 madde için DFA yenilenmiş ve modifikasyon önerilerine uygun olarak kovaryans bağlantıları gerçekleştirilmiştir. Yapılan son DFA sonucunda 19 madde ve 4 faktörlü yapının en iyi uyum değerlerini verdiği saptanmıştı (Tablo 1$)$. Faktör yüklerinin yeterli düzeyde $(0.50-0.79)$, hata varyansları düşük, tüm maddeler için $t$ değerlerinin 0,01 düzeyinde anlamlı olduğu saptanmıştr. Ölçeğin Cronbach Alpha katsayısı 0,88; alt boyutların alpha katsayıları sırasıyla $0.85-0.66-0.85-0.74$ olarak bulunmuştur. Madde toplam korelasyonları 0.33 ile 0.75 aralığında olup yeterli düzeydedir. Saldırganlık ölçeği için gerçekleştirilen DFA'nın başlangıç ve sonucundaki uyum indekslerine ilişkin değerler Tablo 1'de verilmiştir.

Tablo 1. SÖ’nün DFA Uyum İndeksleri Analizi

\begin{tabular}{lcc}
\hline Model Uyum Indeksleri & ilk DFA & Son DFA \\
\hline Madde sayısI & 29 & 19 \\
P & 0.000 & 0.000 \\
X$^{2} /$ sd & 8.19 & 2.72 \\
RMSEA & 0.09 & 0.04 \\
SRMR & 0.10 & 0.04 \\
GFI & 0.76 & 0.95 \\
NFI & 0.68 & 0.93 \\
CFI & 0.70 & 0.96 \\
\hline
\end{tabular}

Portre Değerler Anketi (PDA): Schwartz ve arkadaşları (2001) tarafindan geliştirilen PDA, 40 maddelik altılı Likert tipinde on değer tipini içeren bir ölçme aracıdır. Ölçeğin Türkçeye uyarlaması Demirutku ve Sümer (2010) tarafindan yapılmış ve Cronbach Alpha güvenirlik katsayısı .85 olarak bulunmuştur. Bu çalışmada PDA'nın ergen örneklemi için güvenirlik ve geçerlik analizi yeniden yapılmıştır. Doğrulayıcı faktör analizi (DFA) başlangıcı ve sonucunda elde edilen uyum indekslerine ilişkin değerlere Tablo 2'de yer verilmiştir.

Tablo 2. PDA’nın DFA Uyum İndeksleri Analizi

\begin{tabular}{lll}
\hline Model Uyum Indeksleri & Ilk DFA & Son DFA \\
\hline Madde sayısı & 40 & 25 \\
$P$ & 0.000 & 0.000 \\
$X^{2} /$ sd & 4.32 & 3.67 \\
RMSEA & 0.06 & 0.05 \\
\hline
\end{tabular}




\begin{tabular}{lll}
\hline Model Uyum Indeksleri & ilk DFA & Son DFA \\
\hline SRMR & 0.07 & 0.04 \\
GFI & 0.84 & 0.92 \\
NFI & 0.86 & 0.92 \\
CFI & 0.88 & 0.94 \\
\hline
\end{tabular}

Ölçeğin başlangıçtaki yapısına uygun, madde faktör ilişkisi kurularak yapılan DFA'da model uyum indekslerinin uygun olmadığı ve faktör yükü 0,40'ın altında, hata varyansı 0,90'dan yüksek 15 madde çıkarılıp (M1, M2, M6, M15, M17, M39, M10, M26, M37, M9, M20, M25, M30, M33, M38), modifikasyon önerisine uygun kovaryans bağlantları kurulduktan sonra kalan 25 madde ve 6 faktörlü yapının en iyi uyumu verdiği gözlenmiştir. Faktör yüklerinin yeterli $(0.45-0.85)$, hata varyansları düşük $(S t d . H \leq 0,10)$, tüm maddeler için $t$ değerlerinin 0,01 düzeyinde anlamlı olduğu saptanmıştır. Ölçeğin Cronbach Alpha katsayısı 0,94; alt boyutların alpha katsayıları sırasıyla $0.82-0.83-0.88-0.86-$ $0.77-0.84$ olarak bulunmuştur. Madde toplam korelasyonları 0,36 ile 0,75 aralığında olup yeterli düzeydedir.

Kişisel Bilgi Formu: Katlımcıların cinsiyet ve anne baba eğitim düzeyi ile ilgili bilgiler araştırmacılar tarafindan oluşturulan bir bilgi formu aracılı̆ı̆yla toplanmıştır.

Analiz: Analizlerde ön analizler için frekans dağıımı, aritmetik ortalama, pearson korelasyonu ve hiyerarşik regresyon analizi teknikleri kullanılmıştr. Analizler öncesinde veri seti normallik, otokorelasyon ve çoklu bağlantılılık açısından incelenmiş ve veri setinin parametrik test tekniklerini ve hiyerarşik regresyon analizini kullanmak için uygun olduğu saptanmıştr. Regresyon analizinde cinsiyet ve annenin eğitim düzeyi modele dummy değişken olarak dahil edilmiştir.

\section{Bulgular}

\subsection{Saldırganlık Ölçeği ve Portre Değerler Anketinden Elde Edilen Puanlara İlişkin Betimleyici İstatistikler}

Tablo 3. SÖ ve PDA'dan Elde Edilen Puanlara İlişkin Betimleyici İstatistikler

\begin{tabular}{llcccc}
\hline & Ölçekler & $\mathrm{n}$ & $\bar{X}$ & ss & Çarpıklık \\
\hline \multirow{3}{*}{ Saldırganlık } & Fiziksel saldırganlık & & 3.04 & 1.12 & 0.136 \\
& Sözel saldırganlık & & 2.84 & 1.03 & 0.170 \\
& Düşmanlık & 890 & 2.81 & 1.05 & 0.318 \\
& Öfke & & 2.63 & 1.04 & 0.340 \\
\hline \multirow{5}{*}{ Değer yönelimleri } & Başarı & & 3.61 & 1.47 & -0.085 \\
& Özyönelim & & 4.02 & 1.56 & -0.470 \\
& Evrenselcilik & & 4.20 & 1.33 & -0.586 \\
& İilikseverlik & 890 & 3.39 & 1.72 & 0.130 \\
& Uyma & & 3.93 & 1.36 & -0.463 \\
& Güvenlik & & 3.38 & 1.44 & 0.167 \\
\hline
\end{tabular}

Tablo 3'de görüldüğü gibi, araştırmaya katılan ergenler, saldırganlık ölçeğinden en yüksek puanı fiziksel saldırganlık ( $X=3.04)$, en düşük puanı ise öfke $(X=2.63)$ alt boyutundan almışlardır. PDA açısından ise, en yüksek evrenselcilik $(X=4.20)$, en düşük iyilikseverlik ( $X=3.39)$ ve güvenlik $(X=3.38)$ boyutlarından puan aldıkları saptanmıştr.

\subsection{Saldırganlık Düzeyinin Yordanmasına Ilişkin Bulgular}

İlk olarak, Saldırganlık Ölçeği ve Portre Değerler Anketi'nden elde edilen puanlar arasındaki ilişkileri ortaya koyan korelasyon analizi sonuçları verilmiştir.

Tablo 4. SÖ ve PDA Arasındaki Korelasyon Analizi Sonuçları

\begin{tabular}{lcccc}
\hline & Fiziksel Saldırganlık & Sözel Saldırganlık & Düşmanlık & Öfke \\
\hline Başarı & $-0.37^{* *}$ & $-0.13^{* *}$ & $-0.37^{* *}$ & $-0.13^{* *}$ \\
Özyönetim & $-0.21^{* *}$ & $-0.19^{* *}$ & $-0.24^{* *}$ & $-0.25^{* *}$ \\
Evrenselcilik & $-0.36^{* *}$ & $-0.31^{* *}$ & $-0.28^{* *}$ & $-0.22^{* *}$ \\
İyilikseverlik & $-0.28^{* *}$ & $-0.29 * *$ & $-0.19^{* *}$ & $-0.15^{* *}$ \\
Uyma & $-0.23^{* *}$ & $-0.25^{* *}$ & $-0.13^{* *}$ & $-0.17^{* *}$ \\
Güvenlik & $-0.28^{* *}$ & $-0.22^{* *}$ & $-0.21^{* *}$ & $-0.17^{* *}$ \\
\hline \multicolumn{1}{c}{${ }^{\mathrm{p}<.01}$} & & & &
\end{tabular}


Tablo 4'de görüldüğü gibi; ergenlerin saldırganlık ile değer yönelimleri arasındaki ilişkiyi belirlemek amacıyla yapılan korelasyon analizinde, her iki ölçeğin alt boyutları arasında 0.01 düzeyinde istatistiksel olarak anlamlı ilişkilerin var olduğu saptanmıştır. Buna göre, fiziksel saldırganlık ile başarı ( $r=-.37, p<.01)$; öz yönetim ( $r=-.21, p<.01)$; evrenselcilik ( $r=-$. $36, p<.01)$; iyilikseverlik ( $r=-.28, p<.01)$; uyma $(r=-.23, p<.01)$ ve güvenlik $(r=-.28, p<.01)$ arasında; sözel saldırganlık ile başarı $(r=-.13, p<.01)$; öz yönetim $(r=-.19, p<.01)$; evrenselcilik $(r=-.31, p<.01)$; iyilikseverlik $(r=-.29, p<.01)$; uyma $(r=-$. $25, p<.01)$ ve güvenlik ( $r=-.22, p<.01)$ arasında; düşmanlık ile başarı $(r=-.37, p<.01)$; öz yönetim $(r=-.24, p<.01)$; evrenselcilik ( $r=-.28, p<.01)$; iyilikseverlik ( $r=-.19, p<.01)$; uyma $(r=-.13, p<.01)$ ve güvenlik $(r=-.21, p<.01)$ arasında; öfke ile başarı $(r=-.13, p<.01)$; öz yönetim $(r=-.25, p<.01)$; evrenselcilik $(r=-.22, p<.01)$; iyilikseverlik $(r=-.15, p<.01)$; uyma $(r=-$ $.17, p<.01)$ ve güvenlik ( $r=-.17, p<.01)$ arasında negatif yönde anlamlı ilişkiler vardır.

Ergenlerin saldırganlık düzeylerinin değer yönelimleri cinsiyet ve anne babanın eğitim düzeyi değişkenlerine göre yordanmasına ilişkin yapılan Hiyerarşik Regresyon Analizi Sonuçlarına Tablo 5'te yer verilmiş.

Tablo 5. Saldırganlığın Yordanmasına iliş̧kin Hiyerarşik Regresyon Analizi Sonuçları

\begin{tabular}{|c|c|c|c|c|c|c|}
\hline & Bağımsız değişkenler & B & $\mathrm{SH}_{\mathrm{B}}$ & $\beta$ & $\mathrm{t}$ & $\mathrm{p}$ \\
\hline \multirow{9}{*}{ 1.Adım } & Sabit & 3.926 & 0.086 & & 45.659 & 0.000 \\
\hline & Başarı & -0.078 & 0.022 & -0.149 & -3.588 & 0.000 \\
\hline & Özyönetim & -0.003 & 0.022 & -0.006 & -0.145 & 0.884 \\
\hline & Evrenselcilik & -0.146 & 0.026 & -0.251 & -5.731 & 0.000 \\
\hline & İyilikseverlik & -0.041 & 0.018 & -0.092 & -2.325 & 0.020 \\
\hline & Uyma & -0.007 & 0.022 & -0.012 & -0.299 & 0.765 \\
\hline & Güvenlik & -0.005 & 0.023 & -0.010 & -0.229 & 0.819 \\
\hline & \multicolumn{6}{|c|}{$R=0.436 R^{2}=0.190 \Delta R^{2}=0.184$} \\
\hline & & $F_{(6,883)}=3$ & $p=c$ & & & \\
\hline \multirow{12}{*}{ 2.Adım } & Sabit & 3.765 & 0.132 & & 28.619 & 0.000 \\
\hline & Başarı & -0.075 & 0.022 & -0.143 & -3.445 & 0.001 \\
\hline & Özyönetim & -0.004 & 0.022 & -0.008 & -0.175 & 0.861 \\
\hline & Evrenselcilik & -0.154 & 0.026 & -0.265 & -5.942 & 0.000 \\
\hline & İyilikseverlik & -0.040 & 0.018 & -0.088 & -2.208 & 0.028 \\
\hline & Uyma & -0.005 & 0.022 & -0.008 & -0.213 & 0.832 \\
\hline & Güvenlik & -0.007 & 0.023 & -0.014 & -0.319 & 0.750 \\
\hline & Cinsiyet & -0.018 & 0.058 & -0.010 & -0.303 & 0.762 \\
\hline & Anne eğitim & -0.015 & 0.024 & -0.022 & -0.634 & 0.527 \\
\hline & Baba eğitim & 0.060 & 0.025 & 0.082 & 2.403 & 0.016 \\
\hline & \multicolumn{6}{|c|}{$R=0.442 R^{2}=0.195 \Delta R^{2}=0.187$} \\
\hline & \multicolumn{6}{|c|}{$F_{(9,880)}=23.730 \quad p=0.000$} \\
\hline
\end{tabular}

Tablo 5'te görüldüğü gibi, araştırmanın bağımsız değişkenlerinin yer aldığı ilk modelin istatistiksel olarak anlamlı olduğu $\left(F_{(6 ; 883)}=34.46 ; p<0.01\right)$ ve bağımsız değişkenlerin birlikte saldırganlıktaki değişimin \%18.4'ünü açıkladıkları saptanmıştır. Modelde başarı $(\beta=-0.15 ; t=-3.59 ; p<0.01)$, evrenselcilik $(\beta=-0.25 ; t=-5.73 ; p<0.05)$ ve iyilikseverlik $(\beta=-0.09$; $\mathrm{t}=-2.32 ; p<0.05)$ değişkenlerinin varyansa anlamlı katkı sağladığı ve saldırganlık üzerinde negatif etki oluşturduğu tespit edilmiştir. Cinsiyet, anne-baba eğitimi kontrol değişken bloğunun dahil edildiği ikinci modelin istatistiksel olarak anlamlı olduğu $\left(F_{(9 ; 880)}=23.73 ; p<0.01\right)$, kontrol ve bağımsız değişkenlerin birlikte saldırganlıktaki değişimin yaklaşık \%19'unu açıkladıkları saptanmıştır.

Kontrol değişkenlerinin modele yaptığı katkının anlamlı olup olmadığını belirlemek için $\mathrm{F}$ istatistiğinde meydana gelen değişikliğin istatistiksel olarak anlamlılığı incelenmiş ve değişimin anlamlı olmadığı görülmüştür $\left(\Delta \mathrm{F}_{(3 ; 880)}=2.03\right.$; $p>0.05)$. Diğer bir ifade ile; değer yönelimlerinin saldırganlık üzerindeki etkisi için kurulan ikinci modelde cinsiyet, anne-baba eğitiminin aracılık rolü bulunmamaktadır. Kurulan ikinci modelde başarı ( $\beta=-0.14 ; t=-3.35 ; p<0.01)$, evrenselcilik $(\beta=-0.27 ; t=-5.94 ; p<0.05)$, iyilikseverlik $(\beta=-0.09 ; t=-2.21 ; p<0.05)$ ve baba eğitimi $(\beta=0.08 ; t=2.40 ; p<0.05)$ değişkenlerinin varyansa anlamlı katkı sağladığı, saldırganlık üzerinde başarı, evrenselcilik ve iyilikseverlik değerlerinin negatif yönlü; baba eğitiminin ise pozitif yönlü ve anlamlı etkisinin olduğu saptanmıştır.

\section{Tartışma, Sonuç ve Öneriler}

Sınırları oldukça geniş olan saldırganlık kavramı ve saldırganlığı etkileyen faktörler günümüzde halen anlaşıımaya 
çalışılmaktadır. Psikoloji dünyasının geçmişten günümüze kadar üzerinde en fazla durduğu konulardan bir olan saldırganlık, Bandura (1973) tarafindan en derin kaygı uyandıran insan aktivitesi olarak tanımlanmıştır. Bandura'ya göre saldırgan davranışlar öğrenme ve çevresel deneyimlerin bir sonucudur. Bu araştırmada ergenlerin saldırgan davranışlarının değer yönelimleri, cinsiyet ve ebeveynlerin eğitim durumuna göre yordanması amaçlanmıştır. Araştırmadan elde edilen ilk bulguya göre, araştırmaya katılan ergenlerde en çok fiziksel saldırganlık davranışları görülmektedir. Aktaş ve Güvenç'in (2006) ilköğretim okullarına devam eden ergenler ile gerçekleştirdiği çalışmada ergenlerde en çok saldırganlığın düşmanlık yönünün var olduğu görülmektedir. Bu sonuç yaşla birlikte, ergenlerde saldırganlığı ifade etme biçimlerinde değişim olduğunun bir göstergesi olabilir. Ergenlik döneminde farklı problemlerle karşı karşıya kalan ergenlerin gelişimsel sorumluluklarla baş edebilecek alternatif davranışsal becerilere sahip olmaması (Yavuzer, 2013) ergen saldırgan davranışının nedeni olduğu üzerinde durulmuştur. Saldırganlık ile ilgili farklı bir bakış açısı getiren Ferris ve Grinso (1996), bireyin saldırganlığı, kendini korumak için alternatif bir davranış biçimi olarak da ortaya koyabileceğini belirtmiştir. Saldırganlığın gelişmesinde öğrenmelerin önemli etkisi olduğu düşünülmekle birlikte biyolojik ve çevresel faktörlerin de önemli etkisi olduğu düşünülmektedir. Örneğin, ergenlerin ebeveyn, akran etkileşimlerinde ve medya aracıllğıyla saldırganlık içerikli temalara fazlasıyla maruz kalmaları onların saldırganlık yönünde tutumlar sergilemelerine dolayısıyla saldırganlık davranışlarının artmasına neden olabilir. Atılgan, güçlü ve rekabetçi olmayla toplumsal anlamda ilişkilendirilen saldırganlık içerikli bazı davranışların onaylanmasının saldırganlığın içselleştirilmesine ve normalleştirilmesine neden olabileceği düşünülmektedir. Aynı zamanda bireyin çevresinde herhangi bir problem durumunda çözüm yolu olarak saldırgan eğilim ve davranışlara başvuruluyorsa diğer bir ifade ile birey çevresinde saldırgan bir modele sahipse, saldırgan davranma eğilimi artabilir.

Araşttrmadan elde edilen ikinci bulguya göre; araştrrmaya kattlan ergenler en çok evrenselcilik en az da güvenlik değerine önem vermektedir. Sesli ve Demir Başaran'ın (2016) Anadolu ve meslek lisesi öğrencileriyle gerçekleştirdiği çalışmada da ergenlerin en çok evrenselcilik, en az da güç ile güvenlik ve uyma değerlerine önem verdikleri görülmektedir. Bu durum lise yaş grubunun değer yönelimlerinin birbirine benzerlik gösterdiği şeklinde yorumlanabilir. Hem bireysel hem de toplumsal amaca hizmet eden evrenselcilik değerinin yüksek çıkması, ergenlerin kendi yararları yanında toplumun ve kültürün yararını gözettikleri görülmektedir. Bu sonuç üzerinde günümüz dünyasında artan kültürlerarası etkileşimin de etkili olduğu düşünülmektedir.

Bu araştırmada, öğrencilerin saldırganlık düzeyleri ile değer yönelimleri arasında negatif yönde anlamlı ilişki olduğu saptanmıştır. Bu sonuç, insani değerlerin olumsuz değişkenlerle negatif ilişki gösterdiği, yıkııı tepkilerin ortaya çıkmasına engel olduğu yönündeki görüşü (Karababa ve Dilmaç, 2015) desteklemekte ve ahlaki tutum ile saldırganlık arasında negatif ilişki ortaya koyan (Avcı, 2010), değerleri temel alarak yapılan karakter eğitimi programının (Çokdolu, 2013), barış temelli eğitim programının (Sağkal, 2011) saldırganlık eğilimlerini önemli oranda azalttı̆ı yönündeki bulgular ile tutarlılık göstermektedir. Buna göre; insani değerlerin bireylerin sahip olduğu saldırganlık, şiddet gibi olumsuz tutum ve davranışları azaltarak empati ve demokratiklik gibi olumlu tutum ve davranışları arttırdığı söylenebilir.

Saldırganlığın yordanmasına ilişkin sonuca göre başarı, evrenselcilik ve iyilikseverlik değerlerinin saldırganlığı negatif; baba eğitim düzeyinin ise pozitif yönde yordadığı tespit edilmiştir. Değişkenlerin birlikte saldırganlıktaki değişimin yaklaşık \%19'unu açıkladıkları saptanmıştı. Bu sonuca göre, araştırmanın katılımcılarını oluşturan meslek lisesinde okuyan ergenlerin özgenişletim değer yönelimlerinin yani bireysel başarı ve baskınlığa vurgu yapan "başarı" değerlerinin yükselmesinin ve özaşkınlık değer yönelimleri kapsamında diğerleri ile doğanın iyiliğini istemeye vurgu yapan "evrenselcilik" ve "iyilikseverlik" değer yönelimlerinin yükselmesinin onların saldırganlık düzeylerini azaltacağı anlaşılmaktadır. Diğer bir ifadeyle ergenlerin hem bireysel hem de toplumsal olarak kendilerini ifade edecek değer yapılarına sahip olmaları saldırganlığı azaltmaktadır.

Baba eğitim düzeyinin ergenlerin saldırganlık düzeyinin yordanmasına anlamlı olarak katkı sağladığına ilişkin bulgu Yönet ve arkadaşlarının (2016) babanın eğitim düzeyine göre saldırganlıkta farklılık olduğu yönünde bulgusu ile paralellik göstermektedir. Elde edilen sonuca göre, baba eğitim düzeyi yüksek olan ergenlerin babalarını kendilerinden daha başarılı görme eğilimde olduğu, babalarının seviyesini yakalayamama, hayal kırıklı̆̆ı, korku, kıskançlık gibi durumların yaşanması ile öfke duygusunun ortaya çıkabileceği tahmin edilmektedir. Toplulukçuluğun egemen olduğu kültürlerde baba eğitim düzeyinin yüksekliğinin toplumsal değerlerin varlığının bir göstergesi olduğu göz önüne alındığında, buna karşılık veremeyen ergenlerin öfke duygusu yaşamaları beklenilebilir. Aynı zamanda kendini başarılı bulmama ve diğerlerinin iyiliğini istememe durumunun erkeklerin fiziksel saldırganlık ve öfke düzeylerinin yüksek olmasına yol açabileceği de düşünülmektedir. Ayrıca bu durumun sosyal normların etkisi ile babadan oğula şekillenebileceği; öfkeli davranışların erkekliğin göstergesi olarak algılanmasının etkisi de bulunmaktadır. Ancak bunun, ruhsal ve toplumsal birliktelik açısından sağlıksız bir durum olduğu üzerinde durulmalıdır. Bireysel ve toplumsal olarak sık sık karşılaşılabi-

| Kastamonu Eğitim Dergisi, 27(1), 2019| 
len bir olgu olarak saldırganlık dürtüsü aile ve akran gruplarında toplumsallaşma süreci içinde öğrenilmektedir (Akkaş ve Uyanık, 2016). Yine saldırganlığın gelişmesinde sosyal öğrenmeyle birlikte biyolojik ve çevresel faktörlerin de etkisi olduğu bilinmektedir. Bireysel ve toplumsal değerlere sahip olmanın saldırganlığı azalttı̆ı yönünde bulguların ortaya çıkması, değerlerin büyük oranda aile içinde sosyalleşme ile geliştiği, toplumsal olarak aktarıldığı göz önüne alındığında aile içinde ve sosyal sistemde değerlerin kazandııımasının önemini ortaya koymaktadır. Değerlere sahip olmamanın ortaya koyduğu boşluk özellikle ergenlik döneminde yön ve anlam arayışı içine giren ergeni yaşama dair amaçsızlığa yönelterek saldırganlık gibi riskli davranışlara itmektedir. Saldırganlığın ve değerlerin küçük yaşlardan itibaren içselleştirilerek öğrenildiği düşünüldüğünde bu yönde farkındalık çalışmalarının yapılmasının önemli olduğu düşünülmektedir.

Cinsiyetin saldırganlığın yordanmasına istatistiksel olarak anlamlı katkı sağlayan bir değişken olmadığına ilişkin sonuç cinsiyetin saldırganlık üzerinde önemli etkisi olduğunu ortaya koyan ulusal ve uluslar arası bir çok çalışmanın sonucuyla (Avcı ve Kelleci, 2015; Bersntein ve Gesn, 1997; Boulten ve ark., 2002; Çetinkaya-Yıldız ve Hatipoğlu-Sümer, 2010; Smith ve ark., 2003) tutarlılık göstermemektedir.

Sonuçlar değerlendirildiğinde, başarı, evrenselcilik ve iyilikseverlik değerlerinin yükselmesinin saldırganlığı azalttğı, fiziksel saldırganlık, öfke ve düşmanlık gösteren ergenlerin değerlere daha az önem atfettikleri anlaşılmaktadır. Erkeklerin bu değerlere ilişkin kazanım elde etmeleri ile öfke ve düşmanlık duygularını nasıl yönetecekleri konusunda desteklenmesi gerektiği düşünülmektedir. Ergenler arasında ve özellikle meslek liselerinde okuyan ergenlerin şiddete yönelik tutumlarının oluşumunu etkileyen değişkenlerin incelenmesi ve gençlerin ruh sağlığını koruyucu ve geliştirici, onların bir arada uyumlu yaşamalarını destekleyici psikolojik danışmanlık hizmetlerine ağırlık verilmesi gerektiği önerilmektedir. Saldırganlığın oluşmasında, hem aile bireylerine yönelik algıların, hem de bireyin kendini geliştirme ve diğerlerine duyarlı olma konusunda değer yoksunluğunun etkilerini gözler önüne seren bu çalışma ile genel olarak okullarda, özel olarak meslek liselerini merkeze alarak rehberlik ve psikolojik danışmanlık hizmetlerine hak ettiği önemin verilmesi ve çalışmaların etkisinin arttrılması önerilmektedir. Bu çalışmanın bulguları İzmir ilindeki üç meslek lisesi öğrencileri ile sınırlıdır. Gelecek çalışmaların farklı bölgelerden, farklı lise türlerinde okuyan öğrencilerle gerçekleştirilmesi önerilmektedir.

\section{Kaynakça}

Akkaş, İ. ve Uyanık, Z. (2016). Kadına yönelik şiddet. Nevşehir Hacı Bektaş Veli Üniversitesi, SBE Dergisi, 6 (1), 32-42.

Aktaş, V. ve Güvenç, G. B. (2006). Kız ve erkek ergenlerde saldırgan ve olumlu sosyal davranışlar ile yaş, ilişkisel bağlam ve kişilerarası duyarlıık arasındaki ilişkiler. Hacettepe Üniversitesi Edebiyat Fakültesi Dergisi, 23(2), 233-264.

Arslan, C., Hamarta, E., Arslan, E. ve Saygın, Y. (2010). Ergenlerde saldırganlık ve kişilerarası problem çözmenin incelenmesi. IIlköğretim Online, 9(1), 379-388.

Avcı, A. (2010). Eğitimde şiddet olgusu lise öğrencilerinde şiddet, saldırganlık ve ahlaki tutum ilişkisi Küçükçekmece ilçesi örneği. Doktora Tezi, Marmara Üniversitesi, İstanbul.

Avcı, D. ve Kelleci, M. (2015). Lise öğrencilerinde öfke, saldırganlık ve ruhsal belirtiler arasındaki ilişki. Literatür Sempozyum, 2015 ; 1(5), 34-42.

Aygen, M. ve Açık, Y. (2009). Elazığ ilinde gençlerde şiddete başvurma ya da maruz kalma sıklığı, etkileyen faktörler ve öfke ile ilişkisi. Kocaeli Tip Dergisi, (3),8-17.

Bandura, A. (1973). Aggression: a social learning analysis. New York: Prentice-Hall, Inc.

Başaran, C. (2008). Çeşitli tür liselerde öğrenim gören öğrencilerin saldırganlık düzeylerinin incelenmesi. Yayınlanmamış yüksek lisans tezi. Sakarya Üniversitesi Sosyal Bilimler Enstitüsü, Sakarya

Benish-Weisman, M., \& McDonald, K. L. (2015). Private self-consciousness and gender moderate how adolescents' values relate to aggression. Social Development, 24(4), 766-781.

Berkowitz, L. (1987). Frustration, appraisals, and aversively stimulated aggression. Aggressive Behavior, (14), 3-11.

Bersntein, I., \& Gesn, P. R. (1997). On the dimensionality of The Buss/Perry Aggression Questionnaire. BehaviourResearch \& Therapy, 35(6), 563-568.

Boulten M., Trueman, M., \& Flemington, I. (2002). Associations between secondary school pupils definitions of bullyıng, attitudes towards bulliying: Age and sex differences. Educational Studies; 28(4), 354-369.

Buss, A.H., \& Perry, M. (1992). The aggression questionnaire. Journal of Personality and Social Psychology, (63), $452-459$.

Campano, J.P. \& Munakata, T. (2004). Anger and aggression among filipino students. Adolescence,39(156), 757-764.

Çeşit, C. (2016). Müzik eğitimi alan ve almayan lise öğrencilerinin saldırganlık düzeylerinin incelenmesi. Uluslararası Eğitim Bilimleri Dergisi, 3(9), 70-89.

Çetinkaya-Yıldız, E. ve Hatipoğlu-Sümer, Z. (2010). Saldırgan davranışlarını yordamada çevresel risk, çevresel güvenlik ve okul iklimi algısı. Türk Psikolojik Danışma ve Rehberlik Dergisi, 4 (34), 161-173.

Çokdolu, N. (2013). Karakter eğitimi programının ilköğretim ikinci kademe öğrencilerinin çatışma çözme ve saldırganlık düzeylerine etkisi. Yüksek lisans tezi, Necmettin Erbakan Üniversitesi, Konya. 
Demirutku, K. ve Sümer, N. (2010). Temel değerlerin ölçümü: Portre değerler anketi'nin türkçe uyarlaması. Türk Psikoloji Yazıları, 13(25), 17-25.

Erden, S. ve Yılmaz, S. (2016). İmam hatip lisesi öğrencilerinin akran ilişkilerinin insanî değerler ve öznel iyi oluş düzeyleri açısından incelenmesi. Kalem Eğitim ve Insan Bilimleri Dergisi, 6 (2), 387-414.

Ferris, C.F., \& Grisso, T. (1996). Understanding aggressive behavior in children. (Volume 794). New York: New York Academy of Sciences.pp. $426-794$.

Filiz. A. (2009). Farklı lise türlerindeki öğrencilerin empatik eğilimleri ve saldırganlık düzeylerinin incelenmesi (Kartal ilçesi örneği). Yüksek lisans tezi. Yeditepe Üniversitesi Eğitim bilimleri Enstitüsü

Freedman, J.L., Sears, D.O., \& Carlsmith, J.M. ( 1998 ). Sosyal psikoloji. (Çeviren: Ali Dönmez ). Ankara: İmge Yayınları.

Göldağ, B. (2015). Öğrencilerin şiddet eğilimi düzeyleri ve değer algıları. TÜBAV Bilim Dergisi, 8(4), 1-15.

Güneş, A. (2015). Lise öğrencilerinin şiddet ve değer eğilimlerinin bazı değişkenler açısından incelenmesi (Rize İli Örneği). Yayımlanmamış doktora tezi. Cumhuriyet Üniversitesi, Sivas

Haskan Avcı, Ö. ve Yıldıım, İ. (2015). Prevalence of Violence Tendency in Adolescents. Journal of Theoretical Educational Science, 8(1), 106-124.

İmamoğlu, E. O. ve Karakitapoğlu-Aygün, Z. (1999). 1970'lerden 1990'lara değerler: Üniversite düzeyinde gözlenen zaman, kuşak ve cinsiyet farklılıkları. Türk Psikoloji Dergisi, 14(44), 1-18.

Karababa, A. ve Dilmaç, B. (2015). Ergenlerde İnsani Değerlerin Sürekli Öfke ve Öfke İfade Biçimlerini Yordamadaki Rolü. İlköğretim Online, 14(3), 1149-1158.

Karakitapoğlu-Aygün, Z. ve İmamoğlu, E. O. (2002). Value domains of Turkish adults and university students. Journal of Social Psychology, 142(3), 333-351.

Kepenkçi, Y. ve Çınkır, Ş. (2005). Bullying among Turkish high school students. Child Abuse \& Neglect, 30(2), 193-204.

Kısaç, I.., \& Turan, Z. (2015). Ortaöğretim öğrencilerinin değer yönelimleri. Değerler Eğitimi Dergisi, 13 (29), 495-509.

Koruklu, N. ve Aktamış, H. (2012). Öğretmen adaylarının kavramsallaştırıma boyutundaki değer tercihlerinin incelenmesi. Kuram ve Uygulamada Eğitim Bilimleri, 12(2), 1291-1307.

Kuşdil, M. E. ve Kağıtçıbaşı, Ç. (2000). Türk öğretmenlerinin değer yönelimleri ve Schwartz değer kuramı. Türk Psikoloji Dergisi, $15(45)$, 59-76.

Nugent, W.R., \& Champling, D. (1997). The effects of anger control training on adolescent antisocial behavior, Research on Social Work Practice, 7 (4), 446-462.

Paciello, M., Muratori, P., Ruglioni, L., Milone, A., Buonanno, C., Capo, R., \& Barcaccia, B. (2017). Personal values and moral disengagement promote aggressive and rule-breaking behaviours in adolescents with disruptive behaviour disorders: a pilot study. International journal of offender therapy and comparative criminology, 61(1), 46-63.

Sağkal, A. S. (2011). Barış eğitimi programının ilköğretim 6. sınıf öğrencilerinin saldırganlık eğilimleri, empati düzeyleri ve barışa ilişkin görüşleri üzerindeki etkisinin incelenmesi. Yüksek lisans tezi, Dokuz Eylül Üniversitesi, İzmir.

Schwartz, S. H. (1992). Universals in the contentand structure of values: Theoretical advances and empirical tests in 20 countries. M. P. Zanna, (Der.), Advances in experimental social psychology (Vol. 25) içinde (1-65). NY: AcademicPress

Schwartz, S. H. (1996). Value priorities and behavior: Applying a theory of integrated value systems. C. Seligman, J. M. Olson ve M. P. Zanna, (Der.), The psychology of values:The Ontario symposium, Vol. 8 içinde (1-24). Mahwah, NJ: Lawrence Erlbaum Associates.

Schwartz, S. H., \& Rubel, T. (2005). Sex differences in value priorities: Cross-cultural and multi method studies. Journal of Personality and Social Psychology, 89, 1010-1028.

Schwartz, S. H. \& Sagie, G. (2000). Value consensus and importance: a cross-national study. Journal of Cross-Cultural Psychology, 31 (4): 465 - 497.

Schwartz, S. H., Melech, G., Lehmann, A., Burgess, S., Harris, M. ve Owens, V. (2001). Extending the cross-cultural validity of the theory of basic human values with a different method of measurement. Journal of Cross-Cultural Psychology, 32, 519-542.

Steinberg, I. (2013). Ergenlik. Yayına hazırlayan Figen Çok. 2. Baskı. İmge Yayınevi Ankara

Sesli, Ç. ve Başaran, S. D. (2016). Ortaöğretim öğrencilerinin değer yönelimleri ve özerklik düzeyleri arasındaki ilişkinin incelenmesi/The relation between value tendency and autonomy levels of high school students. Mustafa Kemal Üniversitesi Sosyal Bilimler Enstitüsü Dergisi, 13(34).

Smith, P., Anoniadov, K., \& Cowie, H. (2003). Intervetions to reduce school bullying. Journal of Education; 43(3): $299-312$.

Sussman, S., Skara, S., Weiner, M. D., \& Dent, D. W. (2004). Predictors of violence perpetration among high-risk youth. American Journal of Health Behavior, 28(2), 134-144.

Sümer, N. (2003). Personality and behavioral predictors of traffic accidents: testing a contextual mediated model. Accident Analysis and Prevention, 35, 949-964.

Ünlü, A., Evcin, U., Yılmaz, H. B. ve Dalkılıç, A. (2013). İstanbul devlet liselerinde suç ve şiddet yaygınlığı: Okul türlerinin karşılaştırılması. Anatolian Journal of Psychiatry/Anadolu Psikiyatri Dergisi, 14(2), 152-160.

Yavuzer, Y. (2013). Ergenlerde saldırganlık ve sosyometrik popülerlik arasındaki ilişkilerin incelenmesi. Kuram ve Uygulamada Eğitim Bilimleri, 13(2), 767-780.

Yıldırım, A. ve Abakay, U. (2015). Hokeycilerin iletişim becerileri ve saldırganlık düzeyleri arasındaki ilişkinin incelenmesi. Inönü Üniversitesi Beden Eğitimi ve Spor Bilimleri Dergisi, 2(1), 17-28.

Yiğit, R. ve Dilmaç, B. (2015). Ortaöğretimde öğrencilerinin sahip oldukları insani değerler ile akademik erteleme davranışlarının bazı değişkenler açısından incelenmesi. Dumlupınar Üniversitesi Sosyal Bilimler Dergisi, 31(31).

Yönet, E., Çalık, F., Yaşartürk, F. ve Çimen, K. (2016). Lise Öğrencilerinin rekreatif etkinliklere katılımları ile saldırganlık-şiddet eğilimlerinin incelenmesi. International Journal of Science Culture and Sport (IntJSCS), 4(3), 368-382. 